\title{
ОСОБЛИВОСТІ НАВЧАЛЬНОГО ПРОЦЕСУ ПРИ ВИКЛАДАННІ ДИСЦИПЛІНИ “КЛІНІЧНА ПАТОФІЗІОЛОГІЯ" В УНІВЕРСИТЕТАХ СПОЛУЧЕНИХ ШТАТІВ АМЕРИКИ
}

\author{
М. І. Марущак, О. В. Денефіль, І. Я. Криницька \\ ДВНЗ “Тернопільський державний медичний університет \\ імені I. Я. Горбачевського МОЗ Украӥни”
}

\section{PECULIARITIES OF EDUCATIONAL PROCESS OF "CLINICAL PATHOPHYSIOLOGY" TEACHING IN THE UNIVERSITIES OF UNITED STATES OF AMERICA}

\author{
M. I. Marushchak, O. V. Denefil, I. Ya. Krynytska \\ SHEI "Ternopil State Medical University by I. Ya. Horbachevsky of MPH of Ukraine"
}

\begin{abstract}
Стаття присвячена особливостям навчального процесу при викладанні клінічної патофізіології в університетах Америки. Зокрема автори стверджують, що незалежно від рівня і престижу університету США дисципліна "Клінічна патофізіологія" с важливою складовою у структурі навчання майбутнього медика-професіонала та направлена на розуміння патогенетичних механізмів хвороби конкретного паціснта для вдосконалення практичної медичної допомоги.

This article is devoted to the peculiarities of educational process of Clinical Pathophysiology teaching in the universities of America. In particular, the authors confirm that regardless of the level and prestige of the USA University the "Clinical Pathophysiology" discipline is an important component in the structure of education of future medical professionals and is aimed at understanding the pathogenic mechanisms of the disease of the patient to improve health care practice.
\end{abstract}

Вступ. Перед кожним навчальним закладом високого рівня постає завдання будування власної унікальної організаційної моделі, яка дозволить створити і розвинути стійкі конкурентні переваги. Стратегічне включення ДВНЗ “Тернопільський державний медичний університет імені І. Я. Горбачевського MO3 України" у Європейський простір вищої освіти передбачає переймання світових стандартів підготовки компетентного фахівця, здатного практично діяти, застосовувати індивідуальні медичні техніки та досвід успішних дій у ситуаціях професійної діяльності та медико-соціальної практики. 3 іншого боку, поступове входження університету на міжнародний ринок освіти примусово веде до обов'язкового вивчення дискусійних питань вже не тільки теоретичної, а й сучасної практичної медицини як прагнення країн в умовах глобалізації до покращення медикаментозної терапії та створення нових діагностичних алгоритмів. У цих умовах особливо актуальним $є$ синтез теоретичних знань та використання їх на практиці, що обумовило включення в навчальний процес дисципліни “Клінічна патофізіологія” для студентів 6 курсу медичного факультету нашого університету.
Оскільки основним завданням розвитку клінічної патофізіології $€$ поглиблення та систематизація знань студентів у галузі клінічно значимих розділів загальної патофізіології і найактуальніших тем патофізіології органів та систем, симптоматики, діагностики, а також лікування та профілактики захворювань внутрішніх органів, що відповідають міжнародним стандартам, тому метою нашої роботи було вивчити особливості та спрямованість навчання студентів дисципліни “Клінічна патофізіологія" у вищих навчальних закладах Сполучених Штатів Америки.

Основна частина. Проведений літературний аналіз показав, що у переважній більшості навчальних закладів США для студентів викладається "Клінічна патофізіологія" як окрема дисципліна або ж як елективний курс. Так, у Массачусетському державному університеті Ловелла кафедра клінічної лабораторії і наук про харчування пропонує сертифіковану випускну програму з клінічної патології, яка поєднує в собі теоретичні та технічні знання людської анатомії і фізіології, клінічної хімії, генетики, імунології, мікробіології, гематології, патофізіології, клітинної патології та інших наук, що відносяться до діагно-

() М. I. Марущак, О. В. Денефіль, І. Я. Криницька 
стики, лікування і профілактики захворювань. При цьому обовязковим є завершення попередньо загальної та спеціальної патофізіології [1].

Колорадський університет у Денвері “Metropolitan" готує бакалаврів і магістрів різних спеціальностей. У цьому університеті навчається близько 23 тис. студентів, що більше, ніж у будь-яких інших штатах Америки. Для вивчення інтегративної терапевтичної практики у перелік навчальних дисциплін на 4 курсі включена "Клінічна патофізіологія", яка передбачає 4 академічні години кредиту, що відведені на лекції. Потрібно зауважити, що для відвідування цієї дисципліни обов'язковим є проходження дисципліни “Анатомія та фізіологія людини”. Вивчення дисципліни “Клінічна патофізіологія” у Колорадському університеті передбачає ознайомлення студентів із впливом патологічного процесу на всі основні системи організму. При цьому звертається увага на порушення відповідних біохімічних та метаболічних процесів при певному захворюванні [2].

В університеті медицини та біологічних наук штату Канзас на кафедрі фізіології студенти 2 курсу вивчають елективний курс “Клінічна патофізіологія”. Цей курс призначений для розуміння студентами патофізіології загальних та індивідуальних проявів хвороби пацієнта, що дозволить більш ефективно діагностувати та лікувати хворого. Студенти повинні вміти продемонструвати здатність критично оцінювати свої знання у клінічній практиці, інтегрувати доказову медицину в лікування пацієнтів, показувати розуміння методів досліджень і шляхи вдосконалення практичної медичної допомоги. Для того щоб отримати залік, студент повинен скласти тестовий іспит на рівні 70 \% та вище, подати на розгляд 4 питання 3 найважливіших напрямків клінічної патофізіології та відвідати не менше 16 з 18 годин лекцій [3].

У медичному коледжі Чикаго університету штату Іллінойс на 2 курсі студенти вивчають предмет "Клінічна патофізіологія" протягом 2-х семестрів (разом 9 академічних години кредиту), адресований вивченню патофізіологічних змін, що зумовлюють хвороби. Дана дисципліна тісно пов'язана з фармакологією та патологією, що забезпечує перехід між фундаментальними науками і практичною клінічною медициною. При завершенні предмета студенти повинні вміти використовувати основні наукові знання у практиці загальної клінічної медицини, визначати патофізіологічні зміни, які ведуть до захворювань [4]. Теми, представлені для опрацювання студентами, включають кардіологію, пульмонологію, інфекційні захворювання, гематологію, нефрологію, гастроен- терологію, ревматологію, неврологію, онкологію і ендокринологію. Цікавим є те, що теми лекцій на цьому курсі не є строго визначеними, а відрізняються залежно від конкретної клінічної профорієнтації викладачів.

В університеті штату Індіана предмет "Клінічна патофізіологія” викладають на 3 курсі для студентів бакалаврату і майбутніх медичних працівників з особливим наголосом на клінічний аспект дисципліни. Основні теми для обговорення включають порушення водно-електролітного балансу, патофізіологію серцево-судинної, дихальної, травної, ендокринної, імунної, сечовидільної та нервової систем [5].

Курс клінічної патофізіології в університеті Манчестер штату Нью-Гемпшір охоплює принципи і механізми захворювань на клітинному, тканинному, органному і системному рівнях, в тому числі відповідь на пошкодження клітин, смерть та запалення. Гострі та хронічні патологічні процеси використовуються для кращого розуміння студентами впливу цих процесів на функцію організму [6].

У X'юстонському коледжі Колмана при проходженні “Клінічної патофізіологіі” увага приділяється вивченню патогенезу, прогнозу та терапевтичного лікування захворювань, які часто зустрічаються у клініці внутрішніх хвороб. Матеріал курсу подається у форматі 3 лекцій й 1 практичного заняття, де проводиться обговорення за допомогою вікторини та логічних задач, віртуальних програм з відтворення патологічного процесу. У переліку питань, які розглядаються на заняттях, включено вивчення понять “здоров'я” i “хвороба”, аналіз механізмів розвитку $\mathrm{i}$ прогресування хвороб усіх систем організму, патології хребта, хвороби репродуктивної системи. Додатковим елементом навчання $є$ проект, що включає взаємодію з пацієнтом, формування та патогенетичне обгрунтування діагнозу, вибір тактики лікування. Обов'язковим є попередня підготовка студента як до лекцій, так і до практичного заняття. По закінченні цього курсу слухачі будуть використовувати термінологію, пов' язану з патофізіологією, обгрунтовувати патогенез окремих захворювань та станів у клініці внутрішніх хвороб, вплив старіння, стресу, нерухомості, зловживання наркотиками і алкоголем на перебіг патологічного процесу, розуміти відповідну фармакологічну інформацію і визначати вплив окремих препаратів на організм людини [7].

Висновок. Отже, роблячи загальний висновок, можна сказати, що незалежно від рівня і престижу університету США дисципліна "Клінічна патофізіологія” є важливою складовою у структурі навчання 


\section{ВДОСКОНАЛЕННЯ ВИЩОЇ МЕДИЧНОЇ ОСВІТИ}

майбутнього медика-професіонала та направлена на розуміння патогенетичних механізмів хвороби конк-

\section{Література}

1. Посилання на інформаційний ресурс: http:// www.uml.edu/catalog/graduate/colleges/health_environment/ clinical_lab_nutritional_sci/certificate.htm\# Clinical\%20Pathology

2. Посилання на інформаційний ресурс: http:// catalog.msudenver.edu/preview_program.php? catoid $=13 \&$ poid $=2357 \&$ returnto $=508$ метрополітан

3. Посилання на інформаційний ресурс: http:// www.kcumb.edu/

4. Посилання на інформаційний ресурс: http:// chicago.medicine.uic.edu/departments programs/ ретного пацієнта для вдосконалення практичної медичної допомоги.

program_offices/undergraduate_medical_education/ curriculum/md_program___year_2_/clinical_ pathophysiology/

5. Посилання на інформаційний ресурс: http:// bulletin.ipfw.edu/preview_course_nopop.php? catoid $=19 \&$ coid $=50082$

6. Посилання на інформаційний ресурс: http:// manchester.unh.edu/academics/course-descriptions/BSCI/ 670/Clinical-Pathophysiology

7. Посилання на інформаційний ресурc: http:// coleman.hccs.edu/portal/site/coleman/ 